\title{
Adaptive, Resilient Urban Underground Space (UUS)-Subsid- ence and Economic Impact Spatial Planning Model (USEM): The Extent Development Impact via Cause-Effect Analysis Circa 1980-2050 in Shanghai Megacity
}

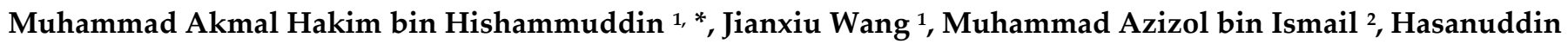
Zainal Abidin ${ }^{3}$, Soheil Sabri ${ }^{4}$, Chin Siong Ho ${ }^{2}$ and Keng Yinn Wong ${ }^{5}$

1 Department of Geotechnical Engineering, College of Civil Engineering (CCE), Tongji University, 200092 Shanghai; Key Laboratory of Land Subsidence Monitoring and Prevention, Ministry of Natural Resources of the People's Republic of China

2 Faculty of Built Environment and Surveying, Universiti Teknologi Malaysia, 81310 Skudai, Johor, Malaysia

3 Faculty of Earth Science and Technology, Institute of Technology Bandung (ITB), Indonesia

4 Department of Infrastructure Engineering, University of Melbourne, VIC, 3010, Australia

5 Faculty of Engineering, Universiti Teknologi Malaysia, 81310 Skudai, Johor, Malaysia

* Correspondence: akmal_hkm@yahoo.com

\begin{abstract}
There are multiple factors determined causing the land subsidence (e.g. man-made and natural-climate change) which have impact on the urban built environment economic spectrum e.g. buildings, properties, infrastructures and land. This paper presents the cause-effect investigation of the causing factors which influence the direct-indirect impacting urban economic factor via multiregression analysis using Shanghai megacity as case study. Factors are selected based on existing UUS-subsidence-economic impact (USEM) framework as well as modification and adaptation from Shanghai Masterplan 2017-2035 (SM 2035) and Sustainable Development Goals (SDGs) 2030. Data are gathered secondarily via open sources e.g. scientific journal articles and reports. The results are parallel to previous studies on the current trend for rapid and unconscious UUS exploration development including tunneling seepage and leakage as leading causes for further land subsidence in Shanghai. A further concrete multi-integrated macro-scale USEM's awareness and knowledge is needed to avoid future costlier damage. The highly regressed causing factors include increasing population, UUS-induced subsidence, underground tunnel leakage, cumulative UUS development and subsidence whereas building prices, reconstruction area ratio, land price, green buildings, tunnel settlement, loss of arable land, number of death and government revenue are the among the most impacted. Officials in Shanghai may further consider results for future USEM masterplans to prevent further unsustainability. It is also found that developing megacity may possess different factors according to their distinct condition.
\end{abstract}

Keywords: Land subsidence; urban underground space; spatial planning model; economic impact; cause-effect analysis; Shanghai; multidisciplinary; sustainability

\section{Introduction}

With climate change threats of accelerated sea level rise $10 \mathrm{~mm}$ per year, extreme weather and tectonic movement, coastal megacities like Shanghai is facing serious challenges within previous, current and possible future of time [1,15], In addition to its function and major economic megacity, the socio-economic development demands for urbanization e.g. rapid urban population growth, demand for space and resources, water demand, and emerging urban underground space (UUS) exploration have put further stress on the megacity [2,3]. With continuous land subsidence issues 6-100mm per year, increased flooding risks and damage to urban economic impact e.g. buildings, properties, 
infrastructures and land have put forward the idea of planning the megacity towards adaptive and resilient state of scenario for future in spite the promising role of UUS development. IGCP Plan by UNESCO [13] is continuously monitoring and funding research projects towards investigating land subsidence in coastal megacities. Hence, this paper presents the extent development impact via cause-effect relation of the multifactor which include causing factors (e.g. land subsidence hazards, pumping locations, flood zone, tectonic, UUS areas and suitability development classes) and direct-indirect economic impact factors (e.g. land, properties, UUS, infrastructures and buildings) [4]. This paper also tries to fulfill the gaps by understanding the extent development impact of UUS-subsidence to economic via developing sustainable, adaptive and resilient spatial modelling. As different urban areas may possess different causative, load and activities that represent different impact, it is imperative to study the ever-complex multidisciplinary spectrum [11]. Hence, this paper provides which factors have the most regression based on the hypotheses and the suits of USEM framework.

\section{Materials and Methods}

The multifactor for cause-effect analysis are derived from the USEM framework [18,14,16-17] and are secondarily synthesised and gathered for study period of 1980-20202030 and logical estimations for 2050 projections. The cause-effect analysis is being used to study the relation of multifactor involving causing or critical determinant factors (e.g. land subsidence hazards, groundwater pumping, probability flooding or inundation zone, tectonic and UUS concentration with the economic impact factors (e.g. land, building/properties, UUS and infrastructures). The method (refer Figure 1) basically involving:

USEM framework = Step 1: Causing hazards $x$ Exposure $\mathrm{x}$ Impacting Economic Factors x Step 2: Space x Time x Vulnerability/Capacity x Step 3: Disaster Risks Scenario Simulation/Modelling x Step 4: Comparative

Figure 1. Simplified basics of USEM model modified from: Abidin et al., 2015; Erkens et al, 2015; Zhang et al, 2018; Peng et al, 20121; Muhammad \& Wang, 2021

\subsection{Cause-effect Determined Main Factors and Indicators}

Cause-effect analysis is the most complex method which analyses the relationships of critical determinants or causing factors with the impact economic factors. Four major causing factors with 41 determined indicators and six major impacting economic factors with 28 determined factors have been carefully selected and integrated deriving from various sources e.g. established subsidence-economic impact framework, SDG 2030 and SM 2035. Datasets for the indicators are input in Excel sheets and secondarily synthesised from publicly available online databases e.g. scientific journals and statistical reports for the study period of year 1980-1990-2000-2010-2020 and logical assumptions for year 20302050 projections. Each indicator has different type of measurement unit varied from mathematical (e.g. km per year) and scoring (e.g. 100\%, 60\% or $40 \%$ ) by year. The causing and impacting factors are then analysed via multiple regression to analyze the relationship between a single dependent variable $(y)$ and several independent variables $(x)$. The objective of multiple regression analysis is to use the independent variables whose values are known to predict the value of the single dependent value [9] using the common following equation:

$$
Y=\beta_{0}+\beta_{1} X_{1}+\beta_{2} X_{2} \ldots+\beta_{i} X i
$$

$\mathrm{Y}$ is dependent variable; $\beta_{0}$ is intercept, $\beta_{\mathrm{i}}$ is slope for $X i$ and $X$ is independent variable. The detailed causing or critical determinate factors $(x)$ and impacting economic factors $(y)$ are enlisted in the following Table 1 and Table 2 . To provide simplicity, only main causing and indicators are shown, whilst the second tier are not. 
Table 1. Causing or critical determinant factors.

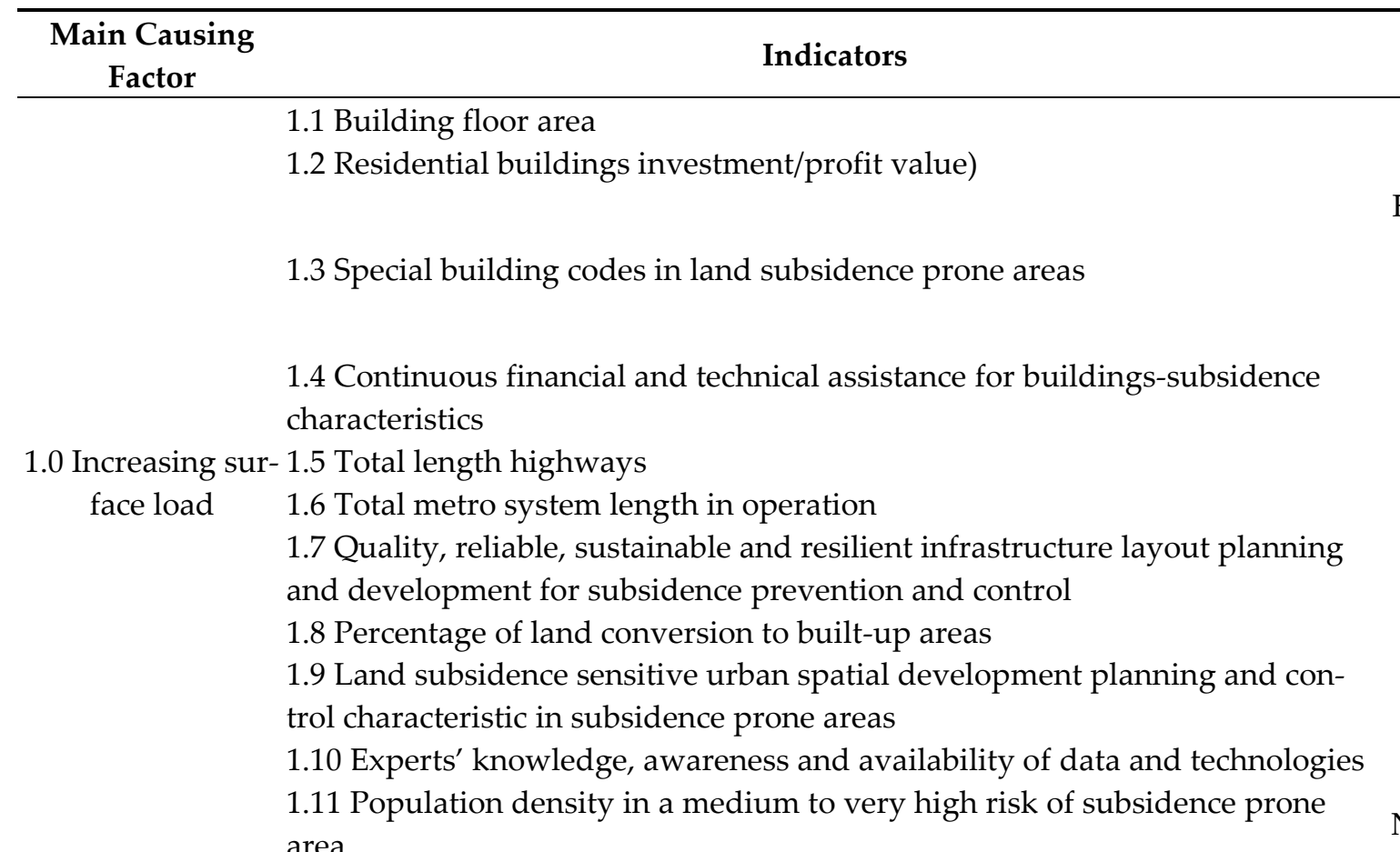

2.1 Underground tunnel leakage

2.2 Cumulative UUS development

2.0 UUS pre-con- 2.3 Construction of foundation pit

struction-opera- 2.4 Pit excavation

tion-post fail- 2.6 Construction of tunnel for transportation

ures/development 2.7 Cut-off effect on groundwater seepage due to underground structures

2.8 Area of tunnel settlement/UUS-induced land subsidence expansion zones

2.9 Historical and potential/probability UUS-induced subsidence rate

Unit

$10^{6} \mathrm{~m}^{2}$

Bill. yuan/year

Fully (F) (100) /In-

termediate $(\mathrm{I})$

(60)/Limited (L)

F/I/L

$\mathrm{km} /$ year

$\mathrm{km} /$ year

$\mathrm{F} / \mathrm{I} / \mathrm{L}$

$\mathrm{F} / \mathrm{I} / \mathrm{L}$

F/I/L

Yes (100)/no (0)

No. of people $/ \mathrm{km}^{2}$

3.1 Total groundwater withdrawal/pumping rate/exploitation (historical and potential) within urban/city center/downtown region

$\mathrm{L} / \mathrm{m}^{2} /$ day

hectare

$\mathrm{m}^{2}$

$\mathrm{m}^{2}$

$\mathrm{km}$

$\mathrm{m}$

hectare

$\mathrm{mm} /$ year

3.2 Groundwater replenishment/artificial recharge for supply resources from surrounding to subsidence prone/urban region

3.3 Total groundwater withdrawal in suburban/transition region

3.4 Groundwater replenishment/artificial recharge for supply resources from surrounding to subsidence prone/suburban region

$10^{6} \mathrm{~m}^{3} /$ year

$\%$, million $\mathrm{m}^{3}$

$10^{6} \mathrm{~m}^{3} /$ year

$\%$, million $\mathrm{m}^{3}$

3.0 Groundwater 3.5 Lack of groundwater extraction limit/groundwater replenishment/ prohipumping/extrac- bition in subsidence/pumping prone areas

$\mathrm{F} / \mathrm{I} / \mathrm{L}$

tion $\quad 3.6$ Weak policies, mitigation, adaptation strategies (need for continuous updates)

3.7 Lack of subsidence awareness, management, policy enforcement

Yes (100)/no (0)

$\mathrm{F} / \mathrm{I} / \mathrm{L}$

3.8 Poor groundwater spatial control, planning and lack or discontinuous monitoring of subsidence characteristics

$\mathrm{F} / \mathrm{I} / \mathrm{L}$

3.9 Lack or discontinues monitoring of subsidence characteristics

$\mathrm{F} / \mathrm{I} / \mathrm{L}$

3.10 Unstrict groundwater banning implementation

$\mathrm{F} / \mathrm{I} / \mathrm{L}$

3.11 Historical and potential cumulative/average subsidence/compression due to pumping rate urban and suburban overall cumulative

$\mathrm{mm} /$ year

4.1 Tectonic movement speed/activities/rate/active fault

4.0 Natural disas- 4.2 Storm surge

ters probability 4.3 Natural soft soil consolidation/compression/coastal condition/alluvial soil 4.4 Seawater level rise

$\mathrm{mm} /$ year

$\mathrm{m} / \mathrm{km}$

$\mathrm{mm} /$ year

$\mathrm{mm} /$ year 
4.5 Subsidence-adaptive and resilient urban development and spatial plan-

ning

$\mathrm{F} / \mathrm{I} / \mathrm{L}$

4.6 Continuous monitoring of subsidence characteristics

$\mathrm{F} / \mathrm{I} / \mathrm{L}$

4.7 Storm surge induced/flood events/inundation probability/ prone

area/zone/designation/subsidence hazards risk expansion vulnerability

$>500 \mathrm{~mm}: \mathrm{km}^{2}$

4.8 Experts' awareness/knowledge/data/ technologies on disaster adaptive ur-

ban spatial planning

$\mathrm{F} / \mathrm{I} / \mathrm{L}$

Table 2. Economic impact factors.

\begin{tabular}{|c|c|c|}
\hline $\begin{array}{l}\text { Main Impacting } \\
\text { Economic Factor }\end{array}$ & Indicator & Unit \\
\hline 1.0 Land & $\begin{array}{l}\text { 1.1 Average benchmarked land price } \\
\text { 1.2 Loss of land resources/arable/cultivated land/area/elevation } \\
\text { 1.3 Decrease/changes/(+-) in land and property values/price } \\
\text { 1.4 Land area developed }\end{array}$ & $\begin{array}{l}\$ / \mathrm{m}^{2} \\
>500 \mathrm{~mm}: \mathrm{km}^{2} \\
\% . \$ / \mathrm{RMB} \\
\mathrm{m}^{2}\end{array}$ \\
\hline 2.0 Underground & $\begin{array}{l}\text { 2.1 Underground structure damage/deformation } \\
\text { 2.2 Tunnel /metro settlement } \\
\text { 2.3 Breaking of underground pipelines and utilities }\end{array}$ & $\begin{array}{l}\$ / \mathrm{m}^{2} / \mathrm{mm} / \text { year } \\
\mathrm{mm} \\
\$ / \mathrm{m}^{2}\end{array}$ \\
\hline 3.0 Infrastructures & $\begin{array}{l}\text { 3.1 Cracking/deformation of permanent constructions, bridges and roads/met- } \\
\text { ros } \\
\text { 3.2 Malfunction of sewerage and drainage system } \\
\text { 3.3 Deterioration of infrastructure } \\
\text { 3.4 Increase in maintenance cost of infrastructure } \\
\text { 3.5 Reconstruction area ratio (housing) }\end{array}$ & $\begin{array}{c}\$ / \mathrm{m}^{2} \\
\$ / \mathrm{m}^{2} \\
\$ / \mathrm{m}^{2} \\
\$ / \mathrm{m}^{2} \\
\text { Billion yuan/year, } \\
\text { million } \mathrm{m}^{2} \\
\end{array}$ \\
\hline $\begin{array}{c}4.0 \text { Build- } \\
\text { ings/properties }\end{array}$ & $\begin{array}{l}\text { 4.1 Building structure damage (replacement/maintenance cost) of old/new/his- } \\
\text { torical buildings } \\
\text { 4.2 Average Building/property/real estate values/prices - residential, commer- } \\
\text { cial, industrial, etc. } \\
\text { 4.3 Abandoned buildings and facilities - due to tilting/damages/sinking/sub- } \\
\text { sidence } \\
4.4 \text { Demand in building and reconstruction sector (+) (value of completed } \\
\text { buildings residential) } \\
4.5 \text { Percentage of newly-built buildings will reach the standards for green build- } \\
\text { ing. E.g. 'Gold' LEED certified, carbon neutrality ZEB by } 2060 \text { China } \\
\text { 4.6 Proportions for rent among newly built residential buildings. }\end{array}$ & $\begin{array}{c}\text { Billion yuan/year. } \\
\text { (Selling prices) } \\
\$ / \mathrm{m}^{2} \\
\text { No. of build- } \\
\text { ings/properties/fa- } \\
\text { cilities } \\
\text { Yuan/m²/year }\end{array}$ \\
\hline \multirow{3}{*}{$\begin{array}{l}\text { 5.0 Socio-economic } \\
\text { activities }\end{array}$} & 5.1 Disruption to economic activities and governance & $\begin{array}{l}\text { F/I/L } \\
\text { Gross Domestic } \\
\text { Product } \\
\text { (GDP)/RMB per } \\
\text { year }\end{array}$ \\
\hline & $\begin{array}{l}5.3 \text { Business interruption for infrastructure/utility services due to increased } \\
\text { coperation and mechanical (O\&M) works and increased failure risk (-) (onshore } \\
\text { disruption) }\end{array}$ & $\mathrm{BI}=\mathrm{T} \times \mathrm{Q} \times \mathrm{V}$ \\
\hline & $\begin{array}{l}\text { 5.4 Government revenue } \\
\text { 5.5 Industry's share of unemployment rate } \\
\text { 5.6 Number of deaths and the number of people affected and substantially de- } \\
\text { crease the direct economic losses relative to global gross domestic product } \\
\text { caused by disasters, including water-related disasters, with a focus on protect- } \\
\text { ing the poor and people in vulnerable situations }\end{array}$ & $\begin{array}{l}\text { Number of popu- } \\
\text { lations in urban } \\
\text { area/ No. (mills) }\end{array}$ \\
\hline
\end{tabular}


5.7 Climate change-adaptation related policies measures in developed-developing countries cooperation spectrum (effectiveness)

$\mathrm{F} / \mathrm{I} / \mathrm{L}$

6.1 Subsidence hazards intensity rate (historical and potential/probability)

6.0 Further land 6.2 Increased Inundated flood hazards and coastal flooding expansion areas subsidence and infrastructures

6.3 Quality of environment condition

$\mathrm{mm} / \mathrm{cm} /$ year

$>500 \mathrm{~mm}: \mathrm{km}^{2}$

$\mathrm{F} / \mathrm{I} / \mathrm{L}$

\section{Results}

The main findings include high regression for spatial modelling, experts' knowledge, population, cumulative UUS development, UUS-subsidence and tunneling leakage. Meanwhile, the low regression includes seawater level rise, tunneling construction and metro length. Kindly note that these results are based on Business as Usual (BaU) while scenarios such as Countermeasures (CM) with full adaptive measures and Worst Case (WC) scenario are yet to be analysed.

\subsection{Ishikawa Cause-Effect Diagram}

Based on preliminary and thorough continuous literature reviews, the main causing factors and impacting economic factors for land subsidence in Shanghai megacity have been determined using Ishikawa fish bone method for easy interpretation into the USEM framework. With integration from SDG 2030 and SM 2035, the concrete cause-effect factors and indicators are determined for USEM framework.

\subsection{High $R$ squared value 0.92-1.00}

Based on preliminary Ishikawa cause-effect determined factors, further datasets are gathered for year 1980,1990,2000,2010,2020,2030 and 2050. It is found that the following indicators e.g. USEM spatial modelling, experts' knowledge, population, cumulative UUS development subsidence, and tunneling leakage have high $\mathrm{R}^{2}$ values. The cause-economic impact of Shanghai in the USEM framework have been influenced mainly by UUS development induced-subsidence, tunneling leakage, and weak spatial modelling/planning. Highest R squared value 0.97-1.00: Lack of awareness/expert's knowledge/technologies and UUS-subsidence-economic adaptive resilient spatial planning model/policies measures (USEM): has the most R squared value equals to 1 with the average buildings price in megacity of Shanghai. It shows that the awareness has the most regression influenced on the building selling prices. This is followed by lack of awareness/knowledge and technologies (0.9789) which have causes further reconstruction area ratio (housing) increase due to damages. Population density, UUS subsidence and tunnel leakage: These factors are causing the most impact respectively on averaged land price, no. of green buildings built and tunneling settlement with $0.97,0.94$ and $0.92 \mathrm{R}$ squared values respectively. Cumulative UUS dev and subsidence: Followed by UUS dev. and subsidence which has quite high impacts on arable land, number of deaths, governance revenue and environment quality (refer Figure 2). 


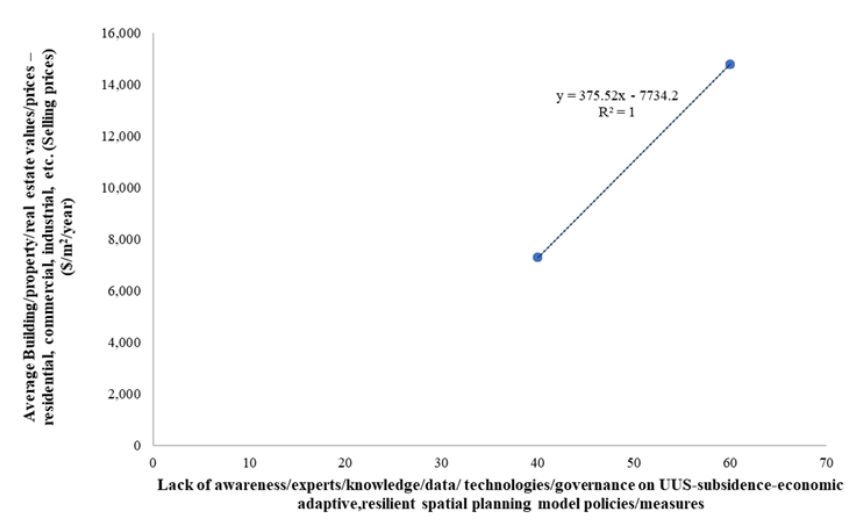

(a)

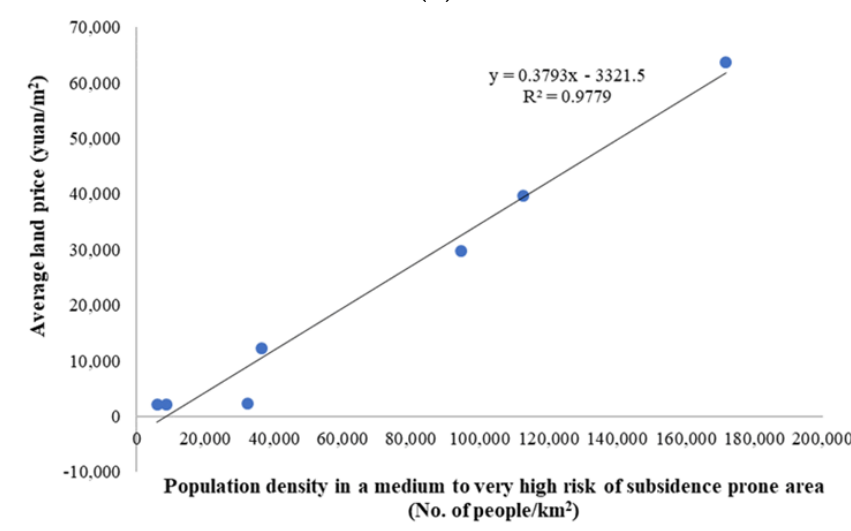

(c)

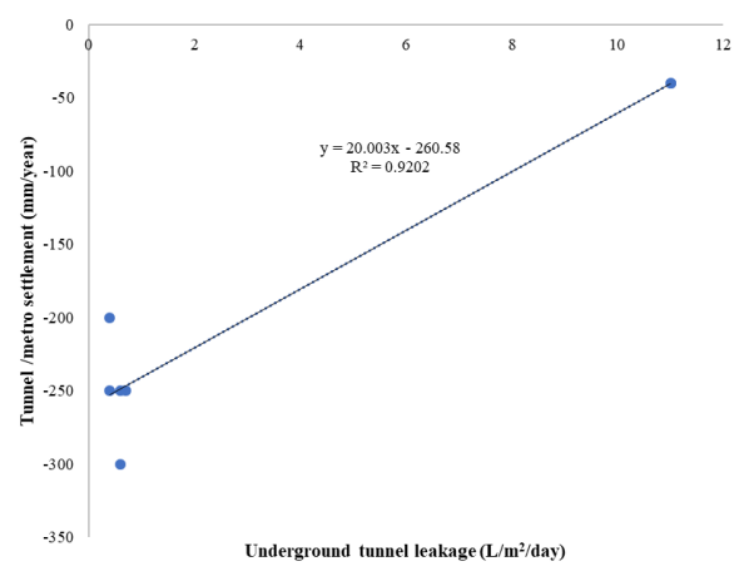

(e)

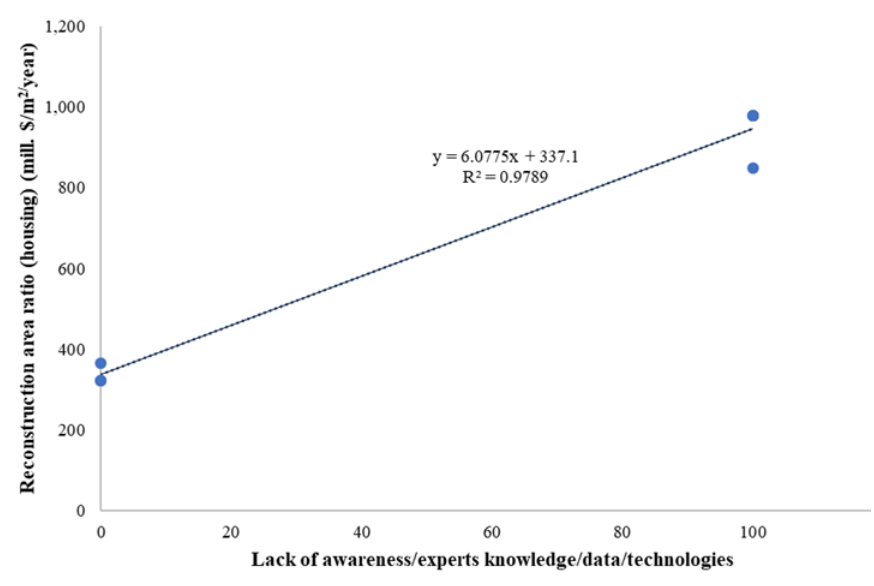

(b)

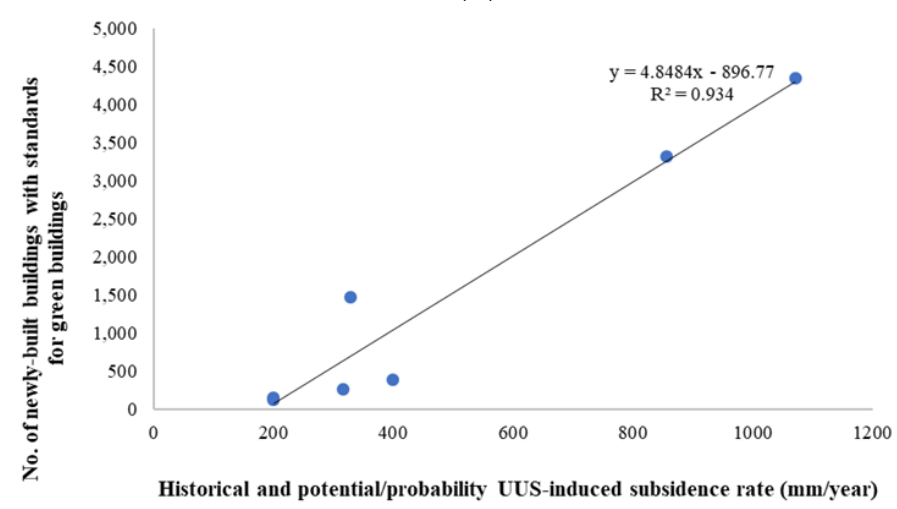

(d)

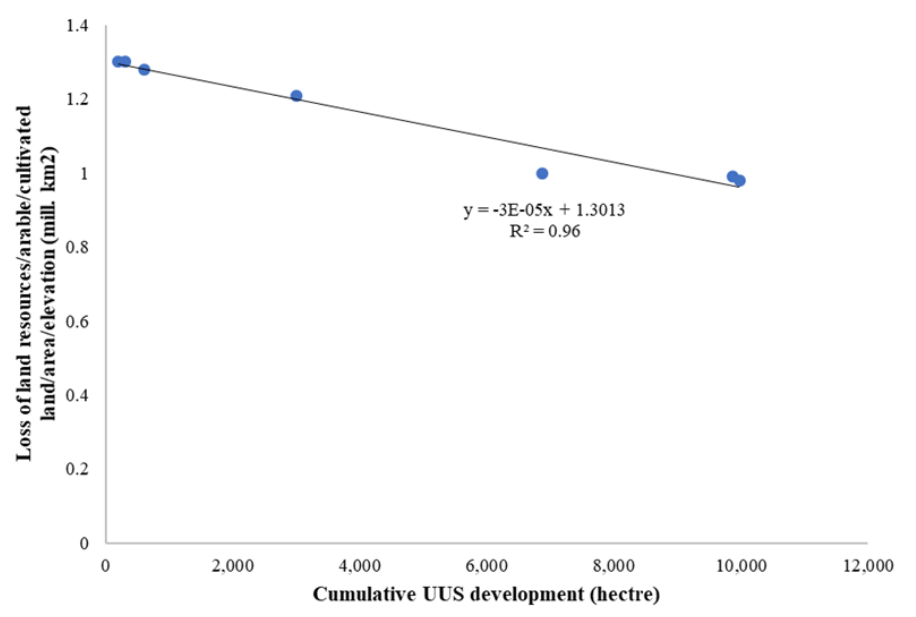

(f) 


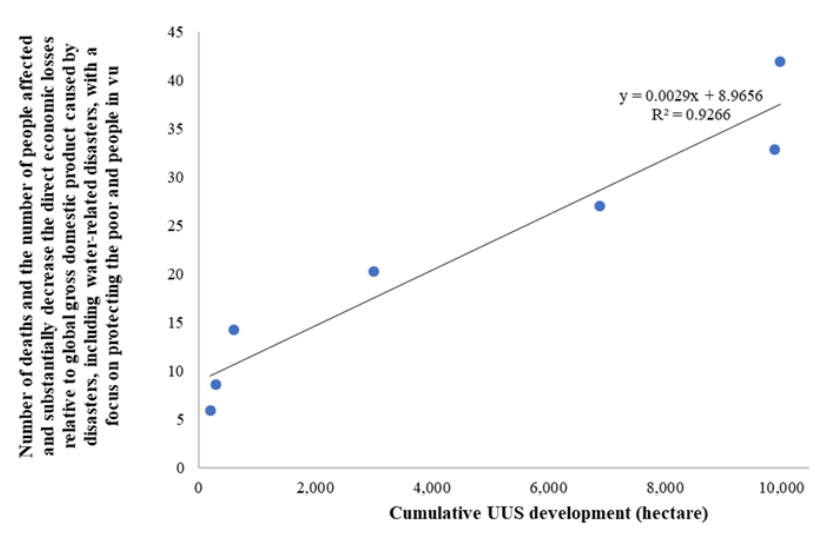

(g)

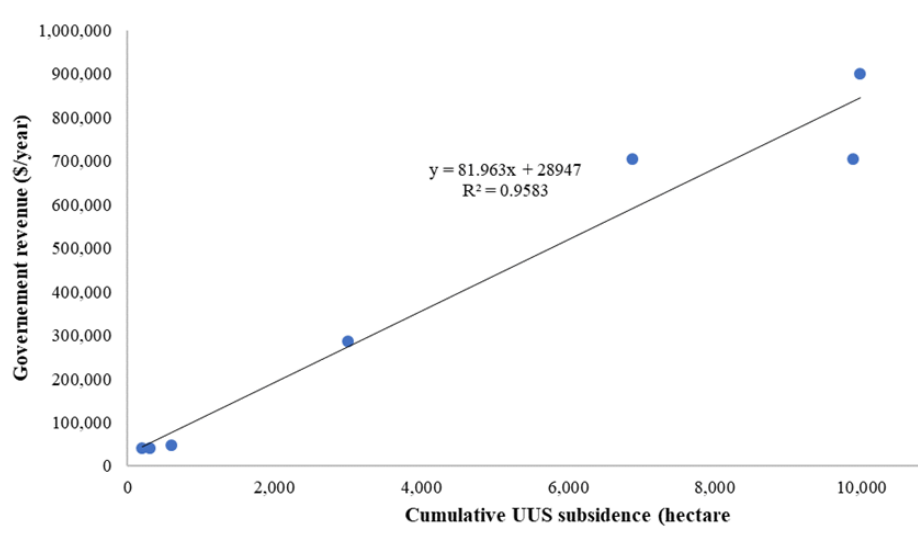

(h)

Figure 2. High regression for causing factors to economic impacting factors range from 0.92-1.00 covers: (a) expert's awareness and knowledge to average building prices; (b) expert's awareness and knowledge to reconstruction area ratio; (c) population to land price; (d) UUS-induced subsidence to number of green buildings; (e) underground tunnel leakage to tunnel settlement; (f) cumulative UUS development to loss of arable land; (g) cumulative UUS development to number of death and (h) cumulative UUS subsidence to government revenue.

\subsection{Least $R$ squared value $0.0007-0.0014$}

Meanwhile for least regressions, to provide simplicity, the causing factors of tunnel construction and total metro length are selected. The causing factors have least regression impact to the economic disruption and unemployment rate, respectively perhaps due to good construction mechanism of tunneling development in Shanghai megacity.

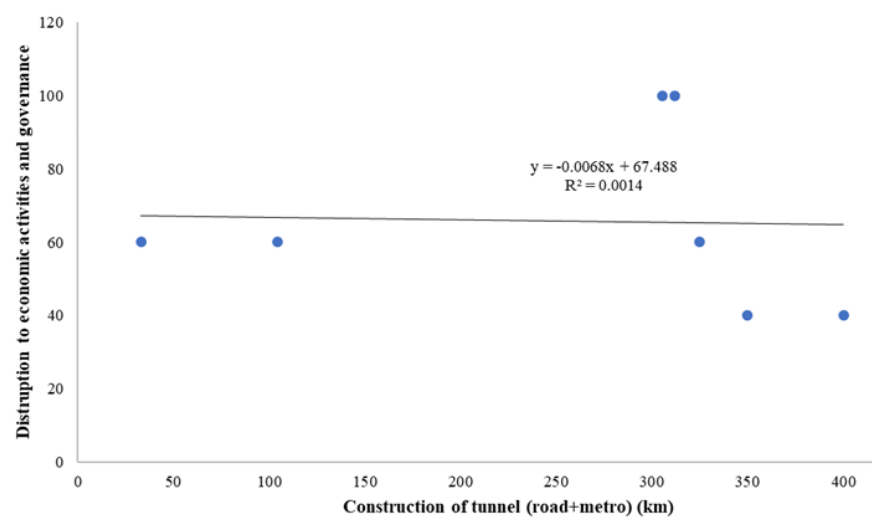

(a)

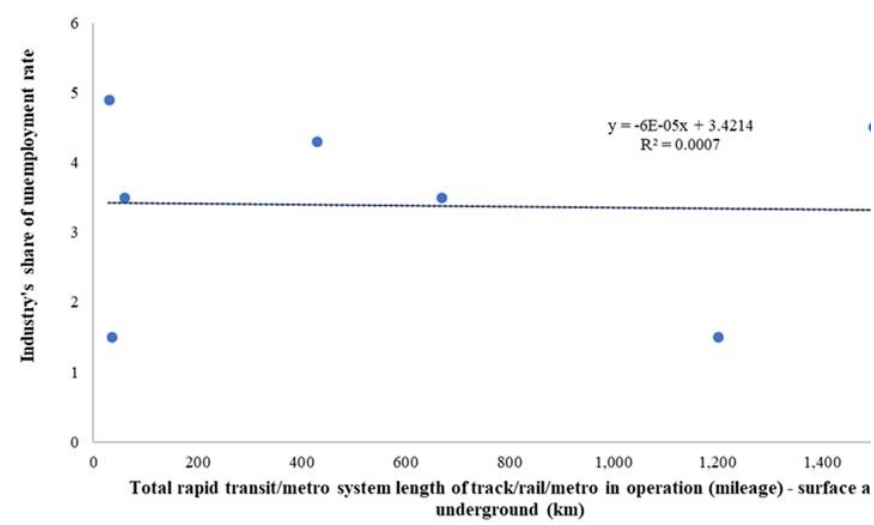

(b)

Figure 2. Low regression of causing factors to economic impacting factors range from 0.0007-0.0014: (a) tunnel construction to economic and governance disruption; (b) total metro length to unemployment rate.

\section{Discussion}

Based on the results, which is parallel to most of the previous studies which emphasis that increasing population, UUS-induced subsidence, underground tunnel leakage and cumulative UUS development and subsidence have high impact on economic factors e.g. building prices, reconstruction area ratio, land price, green buildings, tunnel settlement, loss of arable land, number of death and government revenue. However, new discovery such as the expert's awareness and knowledge on the USEM related field is also substantial. Hence, focuses must be continually given to the highly regression factors in the USEM model which have significant impact to many economic factors including housing prices, reconstruction ratios, averaged land price, no. of green buildings built and tunneling settlement. For low regressions: tunnel construction and metro length, it is quite unexpected 
that the factors have least impact on the economic impact factors. As current UUS development and exploration conducted and expected in Shanghai megacity consists mostly of tunneling for metro and rapid unconscious (UUS) exploration and development have been determined as one of leading causes for continuous land subsidence in Shanghai.

With seepage and leakage in underground tunneling projects have high occurrences due to the megacity's coastal region nature and heavy development load [2,11]. Many adhoc efforts have been pursued however, the awareness and knowledge for multi-integrated macro-scale spatial planning with the emphasis on the multifactor of UUS-subsidence-economic impact resiliency is still lack and needed to avoid future costlier damages $[4,6,11]$. As this step has provide clear multi-relation of the causing-impacting economic factors, further analysis such as spatiotemporal, scenario modelling and comparative of developed and developing megacities are still required. The causing-impacting economic factors may differ in developing megacities in comparison to Shanghai. As noted, the results are based on BaU scenario from 1980-2020-2030-2050, nevertheless, CM and WC scenarios will be analysed in further research conduct.

\section{Conclusions}

This cause-effect results emphasis the high and low regressions of causing-impacting economic factors in the USEM framework. It opens for further research work which involves integrating the statistical data to spatial visual via spatiotemporal analysis, scenarios modelling of CM and WC as well as comparative study.

Author Contributions: Conceptualization, M.A.H. Hishammuddin and J.X. Wang; methodology, M.A.H Hishammuddin, J.X. Wang and M.A Ismail; software, M.A.H. Hishammuddin; validation, M.A.H. Hishammuddin, J.X. Wang and M.A Ismail.; formal analysis, M.A.H. Hishammuddin; investigation, M.A.H. Hishammuddin; resources, M.A.H. Hishammuddin; data curation, M.A.H. Hishammuddin; writing - original draft preparation, M.A.H Hishammuddin; writing - review and editing, M.A.H Hishammuddin; visualization, M.A.H Hishammuddin; supervision, J.X. Wang; project administration, J.X. Wang; funding acquisition, J.X. Wang. All authors have read and agreed to the published version of the manuscript.

Funding: This research is sponsored by the Shanghai Government Scholarship (SGS); Shanghai Municipal Science and Technology Project (18DZ1201301; 19DZ1200900); Key Laboratory of Land Subsidence Monitoring and Prevention, Ministry of Natural Resources of the People's Republic of China (No. KLLSMP202101), and International Geoscience Programme (IGCP) Project (663-Land subsidence in coastal cities).

Conflicts of Interest: The authors declare no conflict of interest. The funders had no role in the design of the study; in the collection, analyses, or interpretation of data; in the writing of the manuscript, or in the decision to publish the results".

\section{References}

1. Erkens, G.; Bucx, T.; Dam, R.; de Lange, G.; and Lambert, J. Sinking coastal cities, Proceedings of the International Association of Hydrological Sciences, Netherlands, 2015; 372:189-198. 10.5194/piahs-372-189-2015 Project: UNESCO Working Group on Land Subsidence.

2. Zhang, W.J; Zhang, L.M.; Wu, X.G.; Liu, Y. Risk Assessment of leakage water of tunnel construction in coastal soft soils. Advances in Economics, Business and Management Research (AEBMR) 2018, 54, 110-115. https://dx.doi.org/10.2991/msmi-18.2018.20

3. Peng, F.L.; Qiao, Y.K.; Sabri, S.; Atazadeh, B.; and Rajabifard, A. A collaborative approach for urban underground space development toward sustainable development goals: Critical dimensions and future direction. Frontiers of Structural and Civil Engineering 2021, 15, 20-45. https://doi.org/10.1007/s11709-021-0716-x.

4. Hishammuddin, M.A.H. and Wang J.X. Towards sustainable, resilient and adaptive urban underground space (uus) exploration, land subsidence and economic impact spatial model (USEM) in shanghai, p.r. china: systematic reviews, model framework, initial results and pre-determined challenges. IOP Conference Series: Earth Environmental Science 2021, 861 072-33, 1-8. Available online: 10.1088/1755-1315/861/7/072033.

5. Abidin, H.Z.; Andreas, H.; Gumilar, I.; and Brinkman, J.J. Study on the risk and impacts of land subsidence in Jakarta. Proceedings of the International Association of Hydrological Sciences 2015, 372, 115-120. https://doi.org/10.5194/piahs-372-115-2015

6. Kok, S. and Costa, A.L. Framework for economic cost assessment of land subsidence. Natural Hazards 2021, 106, 1931-1949 (2021). https://doi.org/10.1007/s11069-021-04520-3.

7. The 17 Sustainable Development Goals. Available online: https://sdgs.un.org/goals (Accessed on 24th July 2021) 
8. Shanghai Masterplan 2017-2035. Available online: http://english.shanghai.gov.cn/newshanghai/xxgkfj/2035004.pdf (Accessed on 18th June 2021).

9. Multiple regression. Available online: https://www.sciencedirect.com/topics/social-sciences/multiple-regression. (Accessed on $25^{\text {th }}$ July 2021).

10. Huai-Na Wu, H.N.; Shen, S.L. and Wu, J.Y. Identification of Tunnel Settlement Caused by Land Subsidence in Soft Deposit of Shanghai. Journal of Performance of Constructed Facilities 2017, 31(6). 10.1061/(ASCE)CF.1943.

11. Sinking cities II - example cases. 1-25. Available online: https://www.deltares.nl/app/uploads/2015/09/Sinking-cities.pdf

12. Abidin, Z.H.; Andreas, H.; Gumilar, I. Disaster risk reduction of land subsidence in Jakarta land subsidence in Indonesian cities land subsidence in Java, Conference: The $2^{\text {nd }}$ International Workshop on Coastal Subsidence, Venice, Italy, 2016, 10.13140/RG.2.1.4448.9206.

13. United Nations Educational, Scientific and Cultural Organisation (UNESCO), International Geosciences Programme (IGCP) UNESCO Annual Report 2020, United. Available online: https://en.unesco.org/sites/default/files/international geosciences programme annual report final 3.pdf (Accessed on 9th October, 2020).

14. Wade, C. M.; Cobourn, K. M.; Amacher, G. S. and Hester, E. T. Policy Targeting to reduce economic damages from land subsidence. water resources research, Water Resources Research 2018, 54 (7), 4401-4416. https://doi.org/10.1029/2017WR022133.

15. He, X. C.; Yang, T. L.; Shen, S. L.; Xu, Y. S. and Arulrajah, A. Land subsidence control zone and policy for the environmental protection of Shanghai. International Journal of Environmental Research and Public Health 2019, 16(15), 1-13. https://doi.org/10.3390/ijerph16152729.

16. Lyu, H. M.; Shen, S. L.; Zhou, A. and Yang, J. Data in risk assessment of mega-city infrastructures related to land subsidence using improved trapezoidal FAHP. Data in Brief 2020, 28, 105007. https://doi.org/10.1016/j.dib.2019.105007

17. Yoo, J. and Perrings, C. An externality of groundwater depletion: land subsidence and residential property prices in Phoenix, Arizona. Journal of Environmental Economics and Policy 2017, 6(2), 121-133. https://doi.org/10.1080/21606544.2016.1226198. 